\title{
Effectiveness of Catching Free Radicals in Cigarette Smoke with Biofilters Made from Bidara Leaf Powder
}

\author{
${ }^{1}$ Agus Mulyono, ${ }^{1}$ Wiwis Sasmitaninghidayah \\ ${ }^{1}$ Jurusan Fisika Fakultas Sains dan Teknologi Universitas Islam Negeri Maulana Malik Ibrahim Malang, Indonesia \\ e-mail: wiwis_hidayah_87@fis.uin-malang.ac.id
}

\begin{abstract}
A number of diseases have been stigmatized as a side effect of smoking and its smoke. Reducing the dangers of smoking by capturing radioactive substances from cigarette smoke is one way to reduce or reduce the level of danger. This study aims to make a filter made from bidara leaf powder to bind free radicals in cigarette smoke. Bidara leaf powder with PEG solution was mixed and stirred until homogeneous with variations in the mass of bidara powder $0.7 \mathrm{grams}, 0.8 \mathrm{grams}, 0.8 \mathrm{grams}, 0.9 \mathrm{grams}$ and $1 \mathrm{gram}$. The product was molded with a $0.7 \mathrm{~cm}$ diameter pipe hose, allowed to dry before being removed from the mold, and heated at a temperature of $105^{\circ} \mathrm{C}$ for 20 minutes. Biofilter matrix using polyethylene glycol (PEG) and egg white, bidara leaf powder as a biofilter filler. The physical characteristics of the membrane were obtained by conducting density and porosity tests with SEM. The effectiveness of the biofilter membrane is known by passing cigarette smoke, then the number of free radicals trapped in the biofilter is analyzed using ESR. The results showed that the use of a biofilter made from bidara leaf powder with a mass of 0.9 grams with an egg white matrix was able to bind $85.7 \%$ of free radicals ( $\mathrm{C}, \mathrm{O}_{2}^{-}, \mathrm{C}$, Peroxy, $\mathrm{CO}_{2}^{-}$, and Hydroperoxides) with $100 \%$ effectiveness, density. 0.893 $\mathrm{g} / \mathrm{cm}^{3}$ and porosity $0.6788 \%$. Testing the characteristics of the biofilter with SEM (Scanning Electron Microscopy) shows the size of the biofilter pores between 2-3 $\mathrm{m}$, while the size of free radicals in cigarette smoke ranges from $20-430 \mathrm{~nm}$. This indicates that the ability to bind free radicals in cigarette smoke is influenced by the antioxidant activity of bidara leaf powder (filler biofilter).
\end{abstract}

Keywords: free radicals, cigarette smoke, biofilter, bidara leaves

\section{Uji Efektivitas Penangkapan Zat Radikal Bebas pada Asap Rokok dengan Biofilter Berbahan Serbuk Daun Bidara}

\section{Abstrak}

Sejumlah penyakit telah distigmakan muncul sebagai efek samping rokok dan asapnya. Pengurangan bahaya merokok dengan menangkap zat radioaktif dari asap rokok merupakan salah satu cara untuk mengurangi atau mereduksi tingkat bahayanya. Penelitian ini bertujuan membuat filter berbahan serbuk daun bidara untuk mengikat zat radikal bebas pada asap rokok. Serbuk daun bidara dengan larutan PEG dicampur dan diaduk sampai homogen dengan variasi massa serbuk bidara 0,7 gram, 0,8 gram, 0,8 gram, 0,9 gram dan 1 gram. Produk dicetak dengan selang pipa berdiameter $0.7 \mathrm{~cm}$, didiamkan sampai kering baru dilepas dari cetakan, dan dipanaskan dengan suhu 1050 C selama 20 menit. Matriks biofilter dengan menggunakan polietilen glitek (PEG) dan putih telur, serbuk daun bidara sebagai filler biofilter. Karakteristik fisis membrane diperoleh dengan melakukan uji kerapatan dan porositas dengan SEM. Efektivitas membrane biofilter diketahui dengan melewatkan asap rokok, kemudian di analisis jumlah radikal bebas yang terperangkap di dalam biofilter dengan menggunakan ESR. Hasil penelitian menunjukkan bahwa penggunaan biofilter berbahan serbuk daun bidara dengan massa 0.9 gram dengan matriks putih telur mampu mengikat $85,7 \%$ jenis radikal bebas (C, O2-, C, Peroxy, CO2-, dan Hidroperoxida) dengan efektivtas 100\%, kerapatan 0,893 g/cm3 dan porositas $0,6788 \%$. Pengujian karakteristik biofilter dengan SEM (Scanning Electron Microscopy) menunjukkan ukuran pori-pori biofilter antara 2-3 $\mu \mathrm{m}$, sedangkan ukuran radikal bebas pada asap rokok berkisar $20-430 \mathrm{~nm}$. Hal ini menunjukkan bahwa yang memiliki kemampuan mengikat zat radikal bebas pada asap rokok dipengaruhi oleh aktivitas antioksidan serbuk daun bidara (filler biofilter).

Kata Kunci: radikal bebas, asap rokok, biofilter, daun bidara

How to Cite: Mulyono. A., Sasmitaninghidayah. W. (2021). Effectiveness of Catching Free Radicals in Cigarette Smoke with Biofilters Made from Bidara Leaf Powder. Jurnal Pendidikan Fisika dan Keilmuan (JPFK), 7(1), 31-38. doi:http://doi.org/10.25273/jpfk.v7i1.9524 


\section{INTRODUCTION}

Smoking is a lifestyle followed by many people(Patana \& Elon, 2019). Smoking habits are now not limited to adult men but have infected teenagers. The people of Indonesia and other developing countries consider smoking an ancestral tradition that is proper and worthy of preservation. Some segments of society even consider smoking as a means of socializing. As a result, smoking becomes something that is very difficult to leave even as if it has become a tradition for some people (Armstrong, 2019). Smoking habits also develop into the selfish nature of smokers who do not hesitate to smoke in public places (Hammado, 2015) The number of smokers every day for all provinces in Indonesia has an average of $24.3 \%$, with the age of smokers ranging from 10 years to more than 60 years (RI, 2018)

The biggest deaths are allegedly caused by cigarettes (Hammado, 2015) due to the compounds that make up cigarettes, including nicotine, nicotyrine, anabasin, myosmin which are stimulants. Meanwhile, cigarette smoke is a complex mixture of chemicals produced by burning tobacco and other additives (Liang et al., 2019). Among the components of cigarette smoke, carbon monoxide (CO) is one of the substances most likely to contribute to health (Talhout et al., 2011). Many empirical approaches such as dilution, filtration and catalytic oxidation are proposed to reduce $\mathrm{CO}$ levels in cigarette smoke. With the right filter, cigarettes have the possibility of switching functions into drugs (filters containing scavengers)(Zahar \& Sumitro, 2011). Cigarette smoke is dangerous because free radical molecules have an imbalance of spin values, so they are very easy to react with other molecules. As a result, chronic diseases such as heart attacks, cancer, cataracts, and decreased kidney function are likely to appear for both active and passive smokers even in the long term. Antioxidants are one of the efforts that can be done to reduce the effects of free radicals.

Free radical scavengers, inactivation of peroxides and other reactive oxygen species, metal chelation, and cooling of secondary lipid oxidation products are some of the activities possessed by antioxidants (Arifin \& Ibrahim, 2018). Antioxidants have an important role for the health of the human body because oxidation reactions involving free radicals can be inhibited and neutralized. The initiation reaction or the propagation of fat/other molecules can be inhibited with antioxidant substances by absorption and neutralization of free radicals or decomposition of peroxides (Parwata, 2016). The addition of an Au-Ag nanoparticle alloy into cigarette filters has been scientifically proven to be able to function as a synergistic catalyst to reduce CO in smoke (Liang et al., 2019). Reactive toxic oxygen (ROS) in cigarette smoke that causes lung damage and other advanced diseases can be bound and controlled by copper tannic acid coordination (CuTA) nanozime. Experiments on mice demonstrated that commercial cigarettes with CuTA nanomyze added efficiently bind to ROS in cigarette smoke, reduce oxidative stress-induced lung inflammation, and minimize smoke-induced lung injury. CuTA nanozime is offered as an efficient ROS binder and opens new opportunities to modify cigarette filters to reduce the toxic effects of cigarette smoke (Lin et al., 2020)

The addition of active ingredients in cigarette filters allows the binding of free radicals in the smoke. Bidara leaves are one of the plants that have antioxidant values tens of times higher than vitamin C(Safrudin \& Nurfitasari, 2018). This antioxidant level is expected to influence and increase the effectiveness of the biofilter in binding free radicals in cigarette smoke. 


\section{METHODS}

The object of this research is a biofilter made from bidara leaf powder with a PEG matrix and egg white with a combined mass of 0.7 grams, 0.8 grams, 0.8 grams, 0.9 grams and 1 gram.

Making a biofilter is done by mixing bidara leaf powder with a PEG matrix or egg white until homogeneous with variations in the mass of bidara powder 0.7 grams, 0.8 grams, 0.8 grams, 0.9 grams and 1 gram. After homogeneous, the product is printed with a $0.7 \mathrm{~cm}$ diameter pipe hose. Then let stand until dry and then removed from the mold. This raw product is then heated to a temperature of $105^{\circ} \mathrm{C}$ for 20 minutes, and the product is ready for use.

Data was collected by calibrating measuring instruments and preparing for treatment of the test product. A biofilter is attached to kretek cigarettes, then it is burned and the cigarette smoke is taken. Data analysis of the effectiveness of the filter made from bidara leaf powder was obtained by analysis of ESR (Electron Spin Resonance) on cigarette smoke without the use of a biofilter and the use of a biofilter with variations in the mass of bidara leaves.

Electron Spin Resonance (ESR) analysis is used to determine the types of free radicals in cigarette smoke by calculating the value of the $g$ factor, the separation of the spectrum due to the interaction of magnetic spins in radicals and the shape of the band which is then used to conclude the types of free radicals identified (Chusniyah \& Akbar, 2019). Pengujian kerapatan biofilter dilakukan dengan mengukur massa dan volume dan kemudian menghitung nilai kerapatan $(\rho)$. Testing the density of the biofilter is done by measuring the mass and volume and then calculating the density value $(\rho)$. The density value is obtained by dividing the mass by the volume. The density value obtained has units of $\mathrm{gram} / \mathrm{cm} 3$. Biofilter porosity testing is done by measuring dry mass, wet mass and volume, then calculate the porosity value (\%). The porosity value is obtained by finding the difference in the wet density minus the dry density then dividing by the dry density multiplied by $100 \%$. Porosity is obtained in units of $\%$.

\section{RESULTS AND DISCUSSION}

The results of ESR on non-filter kretek cigarettes are presented in the following table:

Table 1. Types of Free Radicals in Non-Filtered Clove Cigarette Smoke

\begin{tabular}{ll}
\multicolumn{1}{c}{ Treatment } & \multicolumn{1}{c}{ Types of free radicals found } \\
\hline \multirow{2}{*}{ Non-filtered kretek cigarettes } & Hydroperoxide \\
\cline { 2 - 2 } & $\mathrm{CO}_{2}^{-}$ \\
\hline $\mathrm{C}$ \\
\hline & $\mathrm{Peroxy}$ \\
\hline $\mathrm{O}_{2}^{-}$ \\
\hline $\mathrm{CuOx}$ \\
\hline $\mathrm{CuGeO}_{3}$
\end{tabular}

A biofilter composite membrane made from bidara leaf powder was installed and data was collected 4 times with variations in the mass of bidara leaf powder and PEG matrix, the ESR results were obtained as follows:

Table 2. Types of Free Radicals Found in Kretek Cigarette Smoke with Bidara Leaf Powder Biofilter with PEG Matrix

\begin{tabular}{|c|c|c|c|c|c|c|c|c|}
\hline \multirow[t]{2}{*}{ Test } & \multirow{2}{*}{$\begin{array}{l}\text { Mass of Biofilter } \\
\text { (gram) }\end{array}$} & \multicolumn{7}{|c|}{ Free radical type } \\
\hline & & C & $\mathrm{O}_{2}^{-}$ & Hydroperoxide & Peroxy & $\mathrm{CO}_{2}^{-}$ & $\mathrm{CuOx}$ & $\mathrm{CuGeO}_{3}$ \\
\hline \multirow[t]{2}{*}{ I } & 0,7 & & & & & & Exist & Exist \\
\hline & 0,8 & & & & & & Exist & Exist \\
\hline
\end{tabular}




\begin{tabular}{lrlll}
\hline & 0,9 & Exist & \\
\cline { 2 - 4 } II & 1 & Exist & Exist \\
\cline { 2 - 4 } & 0,7 & Exist & Exist \\
\cline { 2 - 4 } & 0,8 & Exist & Exist \\
\hline III & 0,9 & Exist & Exist \\
\cline { 2 - 4 } & 1 & Exist & Exist \\
\cline { 2 - 4 } & 0,7 & Exist & Exist \\
\cline { 2 - 4 } & 0,8 & Exist & Exist \\
\cline { 2 - 4 } & 0,9 & Exist & \\
\hline 1 & Exist & Exist \\
\cline { 2 - 4 }
\end{tabular}

Table 3. Types of Free Radicals Found in Kretek Cigarette Smoke with Bidara Leaf Powder Biofilter Membrane with Egg white Matrix

\begin{tabular}{|c|c|c|c|c|c|c|c|}
\hline \multirow[t]{2}{*}{ Test } & \multirow{2}{*}{$\begin{array}{c}\text { Mass of } \\
\text { Biofilter (gram) }\end{array}$} & \multicolumn{6}{|c|}{ Free radical type } \\
\hline & & C $\mathrm{O}_{2}^{-}$ & Hydroperoxide & Peroxy & $\mathrm{CO}_{2}^{-}$ & CuOx & $\mathrm{CuGeO}_{3}$ \\
\hline \multirow[t]{4}{*}{ I } & 0,7 & & & Exist & & Exist & Exist \\
\hline & 0,8 & & & & & Exist & Exist \\
\hline & 0,9 & & & & & Exist & \\
\hline & 1 & & & & & Exist & Exist \\
\hline \multirow[t]{4}{*}{ II } & 0,7 & & & Exist & & Exist & Exist \\
\hline & 0,8 & & & & & Exist & Exist \\
\hline & 0,9 & & & & & Exist & \\
\hline & 1 & & & & & Exist & Exist \\
\hline \multirow[t]{4}{*}{ III } & 0,7 & & & Exist & & Exist & Exist \\
\hline & 0,8 & & & & & Exist & Exist \\
\hline & 0,9 & & & & & Exist & \\
\hline & 1 & & & & & Exist & Exist \\
\hline
\end{tabular}

Free radicals in cigarette smoke have two different populations, in the tar phase and in the gas phase (Sukmaningsih, Permana, Santjojo, Wardoyo, \& Sumitro, 2019). The tar phase contains several relatively stable free radicals, while the gas phase of cigarette smoke contains small radicals centered on oxygen and carbon which are much more reactive than the tar phase radicals. Research on the effect of kretek cigarette filters that added juwet fruit extract (Syzygium cumini) as a free radical neutralizer in cigarette smoke was carried out on the liver histology of male mice (Mus musculus). The results showed that juwet fruit extract cigarette filter (Syzygium cumini) could reduce necrosis and fatty liver in male mice. (Mus musculus) exposed to cigarette smoke (Damayanti, Antari, \& Sukmaningsih, 2020). This means that cigarette filters made from juwet fruit extract reduce the negative effects of cigarette smoke, especially in reducing necrosis and fatty liver.

The ESR results show that the use of a biofilter made from bidara leaf powder has the ability to bind free radicals in cigarette smoke. The use of the matrix in the manufacture of biofilters also affects the effectiveness of scavenging free radicals in cigarette smoke. Biofilter with PEG matrix effectively binds free radicals in cigarette smoke in all mass variations of bidara leaf powder. The most effective mass mixture was shown in the addition of 0.9 grams of bidara leaf powder, which was able to capture 6 of 7 types of free radicals in cigarette smoke. 
The types of free radicals in cigarette smoke are short-lived free radicals $(\mathrm{C} \cdot \mathrm{CO} \cdot \mathrm{C}$, $\mathrm{O} \cdot$ and $\mathrm{HO} \cdot$ ) (Ariciu, lonita, \& lonita, 2014). While the types of free radicals found in the ESR test on kretek cigarette smoke without using a filter found 7 types of free radicals, namely: Hydroperoxide, CO2-, C, Peroxy, O2-, CuOx, and CuGeO3. The level of effectiveness reaches $66.67 \%$ which is 2 out of 3 repetitions. The use of egg white matrix for the manufacture of biofilters made from bidara leaf powder also showed a decrease in the number of free radicals. The addition of a mass of 0.9 grams of bidara leaf powder is the most effective composition in scavenging free radicals of cigarette smoke. This composition is able to capture $85.57 \%$ types of free radicals with an effectiveness level of $100 \%$.

These results indicate that bidara leaf powder is effective for capturing free radicals in cigarette smoke. The maximum results were shown by adding 0.9 grams of bidara leaf powder and using egg white as a matrix.

\section{Biofilter Bidara Leaf Powder Characterization Results}

Characterization testing is used to obtain the value of porosity and density. SEM (Scanning Electron Microscope) was used for this (porosity) test with the following result:

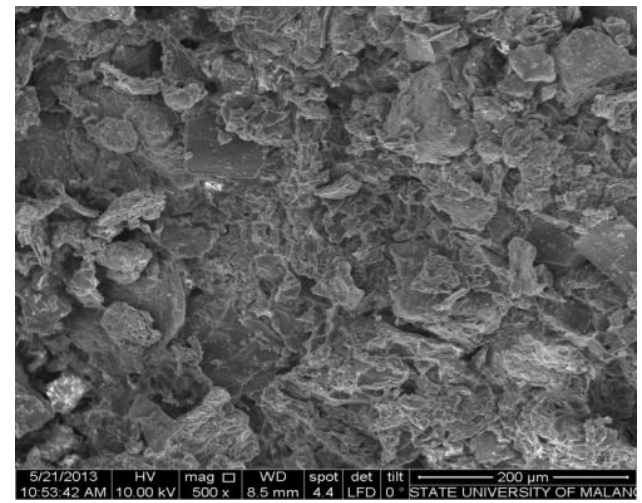

Figure 1. Results of SEM Biofilter of bidara leaf powder ( 0.9 grams) with egg white matrix

By using the Origin 2019-b porosity analysis, this SEM image can be converted into 3D form.

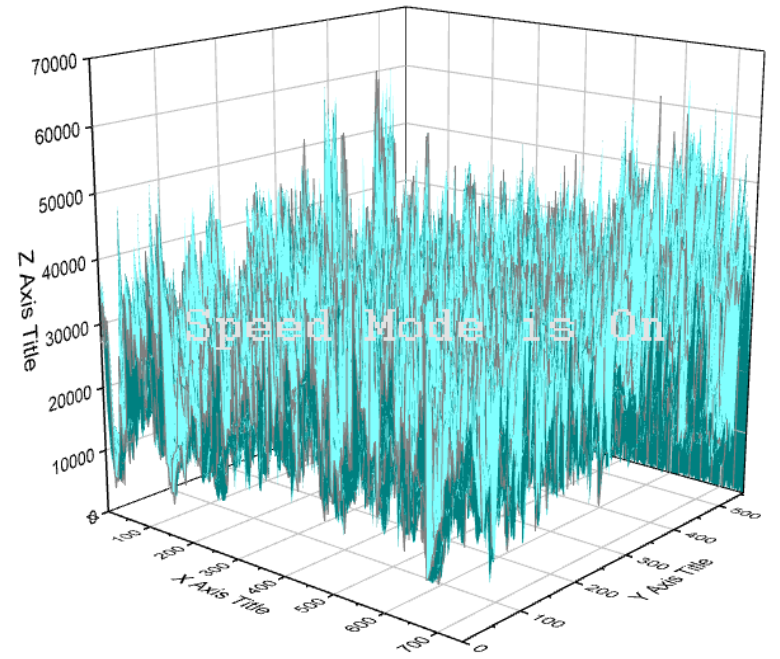

Figure 2. 3D Structure of SEM Biofilter of bidara leaf powder (0.9 grams) with egg white matrix

Analysis of the structure of the 0.9 gram bidara leaf powder biofilter showed a porosity value of $62.94 \%$. This shows that the pore volume of the filter made with 0.9 gram bidara leaf powder is $12.94 \%$ more than the volume of the solid filter, so 
that the biofilter can be effectively used to filter cigarette smoke. The size of the biofilter pores is obtained between 2-3 $\mathrm{m}$, while the size of free radicals in cigarette smoke ranges from 20-430 nm (Delaval et al., 2019). This shows that what affects the absorption of free radicals in kretek cigarette smoke is the content of the biofilter filler (bidara leaf powder), not the pores.

The results showed that the total flavonoid content obtained from the ethanol extract of bidara leaves (Ziziphus spina-christi L.) was $1.5312 \%$, and IC50 $90.9584 \mathrm{ppm}$. This value indicates that the ethanol extract of bidara leaves (Ziziphus spina-christi L.) has the potential as a strong antioxidant(Haeria, Andi, \& Science, 2016). The absorption of free radicals in kretek cigarette smoke by a biofilter made from bidara leaf powder may be influenced by the high antioxidant substances contained in bidara leaf powder.

The density and porosity tests result of the biofilter are presented in the following diagram.

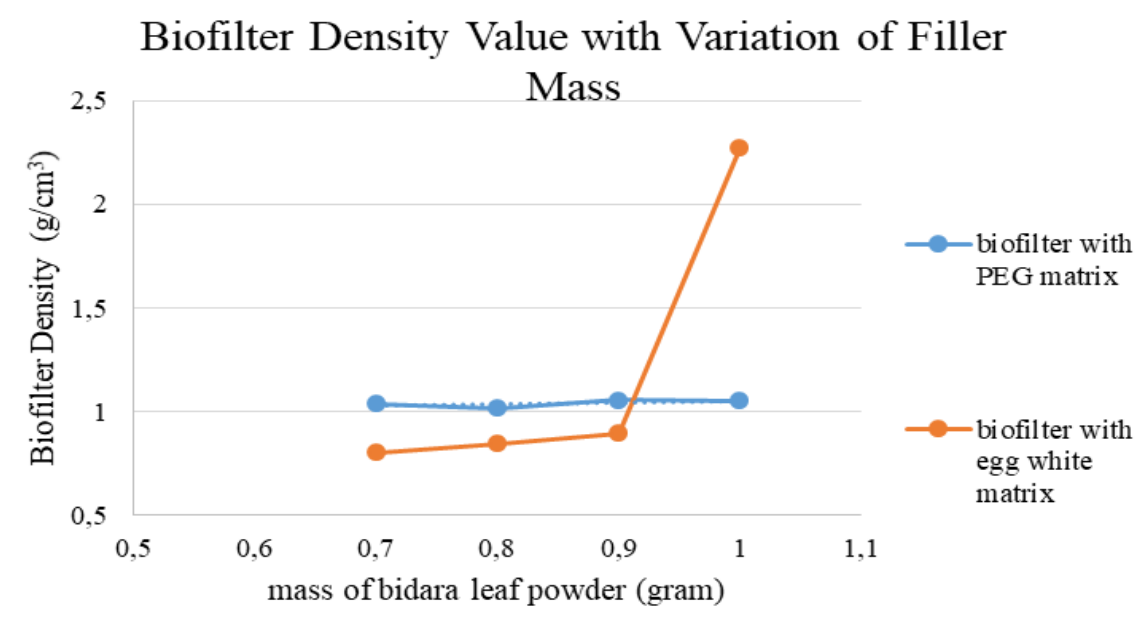

Figure 3. The density value of a biofilter made from bidara leaf powder with variations in mass

The density value of the biofilter is directly proportional to the addition of the mass of bidaran leaf powder. The highest density was obtained by adding $1 \mathrm{gram}$ of bidara leaf powder with egg white matrix. The use of egg white matrix resulted in a more significant increase in density compared to the use of PEG matrix in biofilters made from bidara leaf powder. The higher the filter density, the wider the filter touch area (Nurmayanti \& Hastuti, 2014), which in this case the wider field of free radical scavenger substances from cigarette smoke. However, from the results of the ESR the addition of mass did not significantly affect the type of free radical substance that could be bound by the biofilter. The use of masses of 0.7 grams, 0.8 grams, 0.9 grams and 1 gram both have the ability to bind $85.7 \%$ of free radicals. 


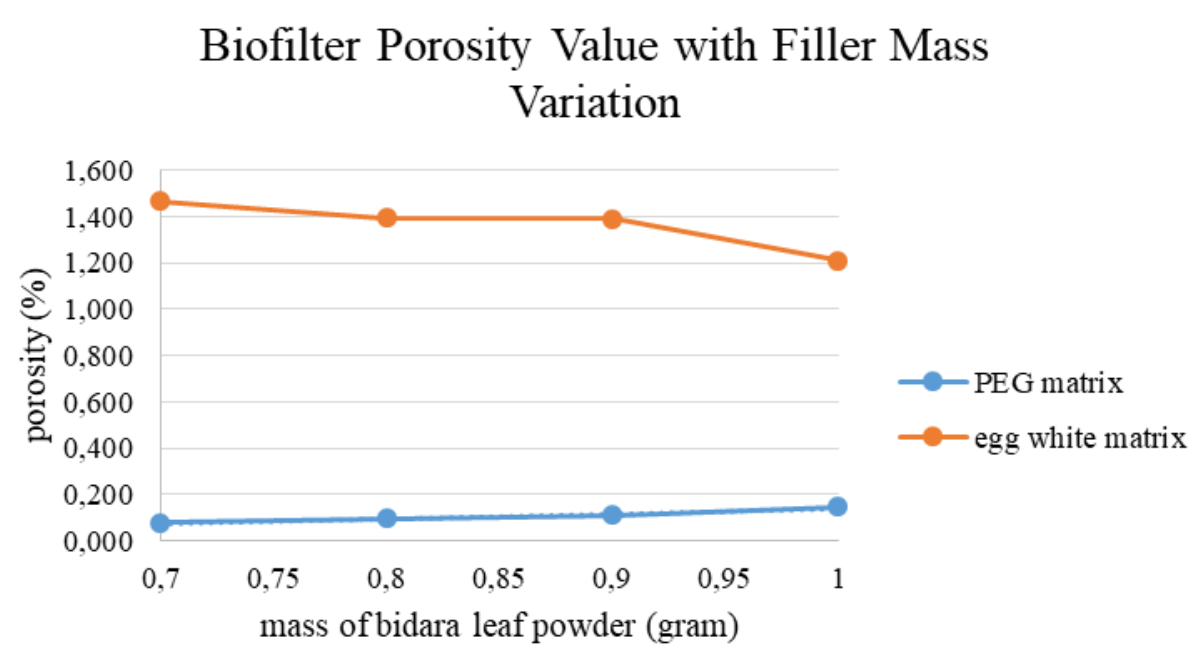

Figure 4. The porosity value of a biofilter made from bidara leaf powder with variations in mass

The porosity value based on the SEM value is $62.94 \%$, while by calculating the dry density and wet density of the biofilter material, the porosity value is obtained as shown in Figure 4. Biofilter with the use of PEG matrix has a lower porosity value than the porosity value in a biofilter with a matrix egg whites. The higher the porosity value, the denser the distance between the particles so that the volume of the substance that flows will be less, while the low porosity value indicates the more volume of the substance that passes through the biofilter (Nurmayanti \& Hastuti, 2014).

The SEM results show that the size of the biofilter made from bidara leaf powder is between 2-3 m, while the size of free radicals in cigarette smoke ranges from 20-430 nm. This measurement was carried out on samples with a mixture of 0.9 grams of bidara leaf powder with an egg white matrix. So the binding of free radicals in biofilters made from bidara leaf powder is not affected by the value of porosity and filter density (substances tested in the gas phase), but is influenced by antioxidant activity in bidara leaf powder.

\section{CONCLUSION}

Composite membranes made from bidara leaf powder are able to absorb $85.7 \%$ of the types of free radicals present in kretek cigarette smoke, namely 6 types of 7 types of free radicals, namely Hydroperoxides, CO2-, C, Peroxy, O2-, $\mathrm{CuOx}$, and $\mathrm{CuGeO}$. The effectiveness of the absorption of free radicals from cigarette smoke by a biofilter is influenced by the antioxidant activity of bidara leaf powder. The porosity and density values have no effect on the ability of a biofilter made from bidara leaf powder to capture free radicals in cigarette smoke. The most effective composition is to mix 0.9 grams of bidara leaf powder with an egg white matrix.

This study only discusses the types of free radicals that can be bound by biofilters made from bidara leaf powder, but the percentage of binding of each type of free radicals by biofilters still requires more in-depth research. 


\section{REFERENCE}

Ariciu, A.-M., Ionita, G., \& Ionita, P. J. R. R. C. (2014). AN EPR SPIN-TRAPPING STUDY OF FREE RADICALS IN CIGARETTE SMOKE. 59(9), 781-787.

Arifin, B., \& Ibrahim, S. J. J. Z. (2018). Struktur, bioaktivitas dan antioksidan flavonoid. 6(1), 21-29.

Armstrong, S. (2019). Pengaruh rokok terhadap kesehatan.

Chusniyah, D. A., \& Akbar, R. (2019). PENENTUAN KARAKTER MAGNETIK OBAT DAN LIMBAH BALUR DENGAN ELECTRON SPIN RESONANCE (ESR). Paper presented at the Prosiding Seminar Nasional Pakar.

Damayanti, I. A. M., Antari, N. W. S., \& Sukmaningsih, A. A. S. A. J. J. R. K. N. (2020). Uji Aktivitas Filter Buah Juwet (Syzygium cumini) sebagai Peluruh Radikal Bebas Terhadap Paparan Asap Rokok pada Hati Mencit Jantan (Mus musculus L.). 4(2), 14-20.

Delaval, M., Egli, D., Schüpfer, P., Benarafa, C., Geiser, M., \& Burtscher, H. J. J. o. a. s. (2019). Novel instrument to generate representative e-cigarette vapors for physicochemical particle characterization and in-vitro toxicity. 129, 40-52.

Haeria, H., Andi, T. J. J. o. P., \& Science, M. (2016). Penentuan kadar flavonoid total dan aktivitas antioksidan ekstrak etanol daun bidara (Ziziphus spina-christi L.). 57-61.

Hammado, N. J. D. (2015). Pengaruh Rokok Terhadap Kesehatan Manusia. 2(2).

Liang, M., Zhang, G., Li, R., Feng, Y., Wang, J., Hou, P. J. M., \& Letters, N. (2019). Green synthesis of $\mathrm{Au}-\mathrm{Ag}$ alloy nanoparticles using Lysimachia christinae polysaccharide and its application for reducing $\mathrm{CO}$ in cigarette mainstream smoke. 14(8), 865-867.

Lin, S., Cheng, Y., Zhang, H., Wang, X., Zhang, Y., Zhang, Y., . . Wei, H. J. S. (2020). Copper tannic acid coordination nanosheet: a potent nanozyme for scavenging ROS from cigarette smoke. 16(27), 1902123.

Nurmayanti, V., \& Hastuti, E. J. J. N. J. F. d. A. (2014). Karakterisasi sifat fisis membran polimer matrik komposit (PMC) dari karbon aktif tempurung kelapa untuk adsorbsi logam berat pada minyak goreng bekas.

Parwata, M. J. K. T. P. P. U. U. (2016). Bahan Ajar Antioksidan.

Patana, D. H., \& Elon, Y. J. J. I. K. D. (2019). FENOMENA MEROKOK PADA REMAJA PUTRI: STUDI KUALITATIF. 14(4), 390-402.

RI, K. J. B. P. d. P. K. (2018). Laporan Nasional RKD2018 FINAL. pd f. 198.

Safrudin, N., \& Nurfitasari, F. J. J. I. (2018). Analisis senyawa metabolit sekunder dan uji aktivitas antioksidan dengan metode DPPH (1,1-diphenyl-2-picrylhydrazyl) dari ekstrak daun bidara (Ziziphus spina-christi L.). 4(2), 11-20.

Sukmaningsih, A. A., Permana, S., Santjojo, D., Wardoyo, A. Y. P., \& Sumitro, S. B. (2019). The potency of java plum (Syzgium cumini) fruit extract as free radical scavenging in cigarette smoke. Paper presented at the AIP Conference Proceedings.

Talhout, R., Schulz, T., Florek, E., Van Benthem, J., Wester, P., Opperhuizen, A. J. I. j. o. e. r., \& health, p. (2011). Hazardous compounds in tobacco smoke. 8(2), 613-628.

Zahar, G., \& Sumitro, S. B. J. M. B. P. I. J. (2011). Divine kretek rokok Sehat. 